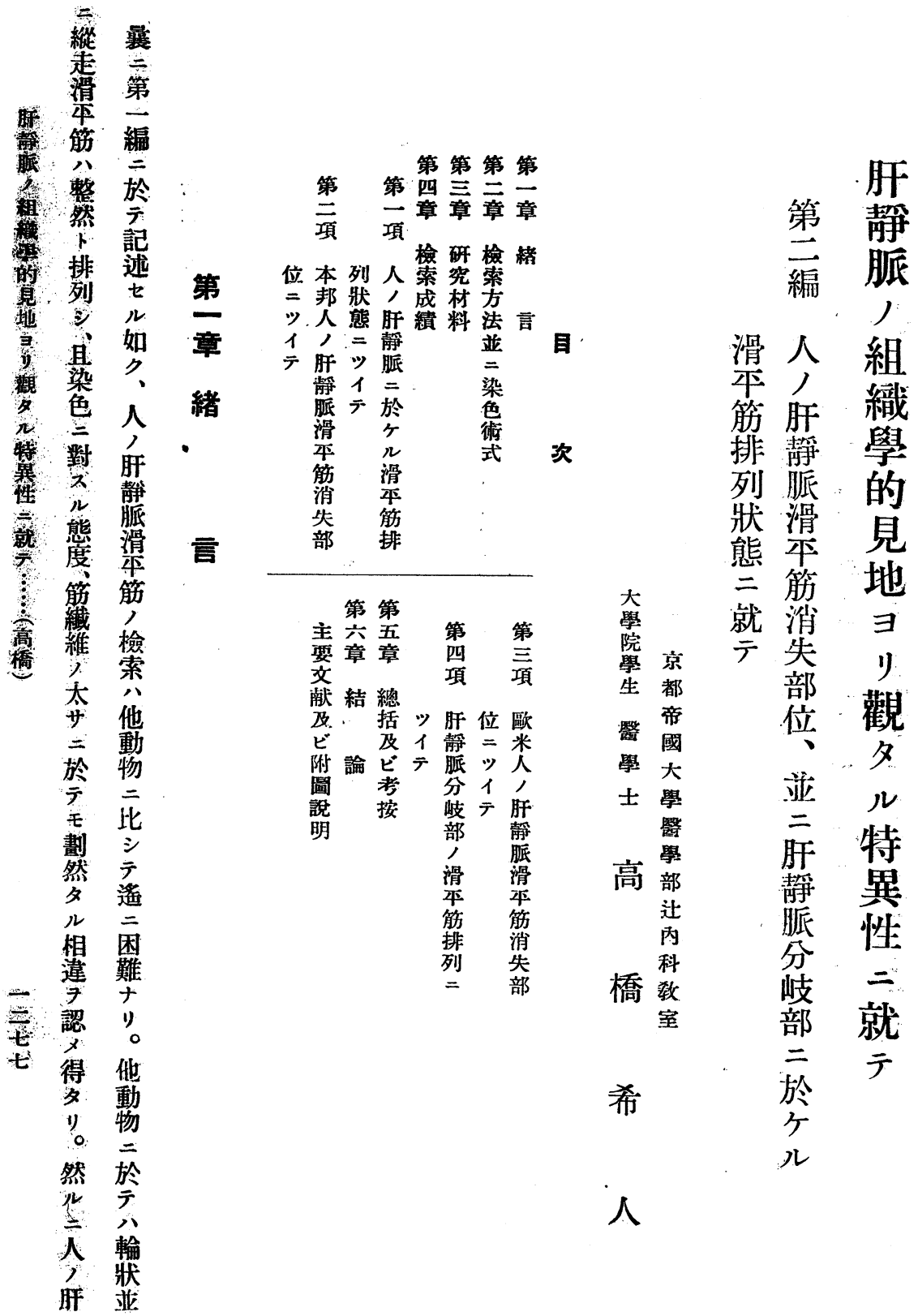


滑ル 錯き 輸該 午 $シ$ 两管索 筋以テ 滑 7 方 ノテ、作本末法 檢、爲成 笳 梢 心 出血二シ, 第 二管 輪 テ 㘕 デ 二 直 狀 遺 別追 編 * 徑、漏二究二 最)縱ナ適方於 モ計走キ表方 注测阙 7 可記 意八滑期切檢載 ス的筇 り片 血 キ 少。作忩卜 八期 鑑 然り嚴同

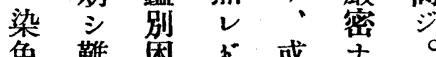
色難囷或ナ 方キ離害 文洼管 ナ能ル蔡血意呆 リ $7 コ$ 問 管 少 梢 限卜題 壁下 部

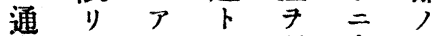
常云”。方斜豫檢 ○. 於 下正留 望徑當 キ 龅、靜一 一 $シ$ 二 組 脈 切 測 テ リ近織八片定八 ン: 心 分二 シ 組 -ラフ岐於、織 工亦多示然片 才コルク縱儿中 济、走後二

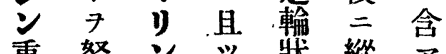
重努 $ソ$ 狀縦 染 $x$ 固 コ爾斷 色夕定, 滑 シ 夕 二リ二分平、ル 於 ? 业岥筋或 適 テ リ部 7 八當 八采同橫ナ

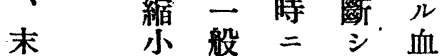
梢不二見テ管 部 ル 滑出、 分 傾本 要縦擇 二 向筋易走 ビ i 八ソ 产如静

尹殆ノ文滑》脈 特文献本 顯二 二意献二筋著 於 詳二三之間ナテ䏕 細留於丹分学 二メテ 徵 結 差、脈 檢ズモス締子屋 索、旰ル織見之組 シ 惟靜 二 三 ス。 第 起 二 脈人富。态的

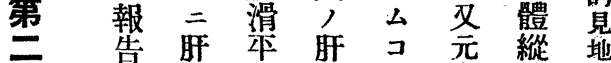
章 ス贜筋靜卜來走 $\exists$

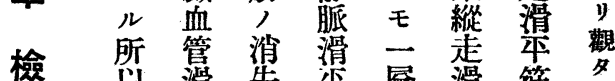

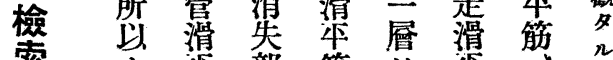

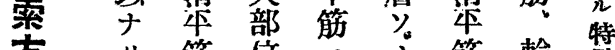
方 り筋 位 三; 筋 輪 異 法。排 ス 關 爁云狀 性 並烈 三

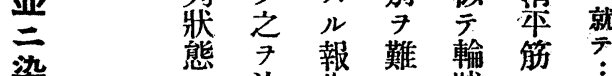
八決告另狀二 該 定只 ラ二之 血 ス 甚 シ 走 7 高 管 ル 少 厶 行 別 橋 ノコク ス チ 機ト、得 能ナ向 モ它

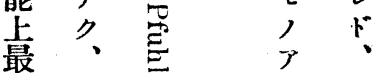
モ

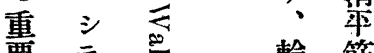
要 亏 胥 輪 筋 三 胿靜

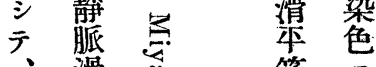
滑 算 三 之本高 二 對 余笳窇 似 ガ複 施 態

人嚾尔走度 年 ル 靜 排禀毛物 脈列, 滑云冚於 筋至焉导 り 少

且 カ 
シ 染 梢 乷 不

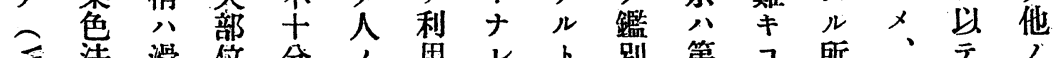

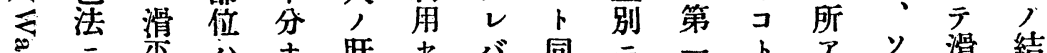
肝 常二采公ナ肝

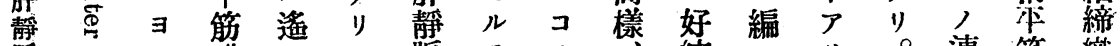

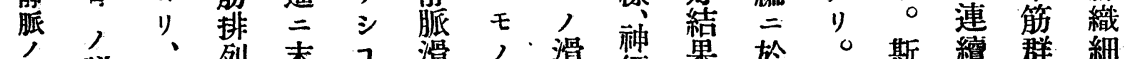

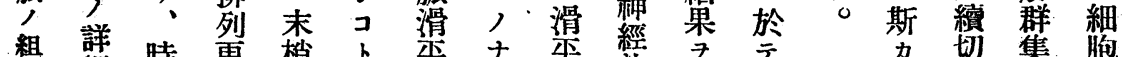
織細時更梢卜本ナ本染

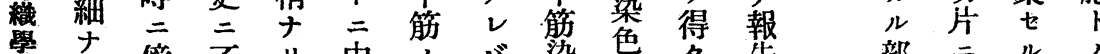

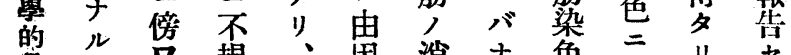

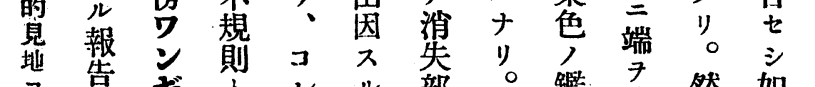

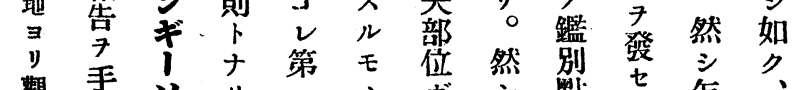

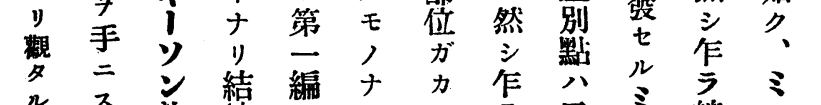

ル

珙 7 色織 於 シ

性、得へ

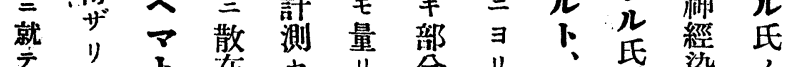

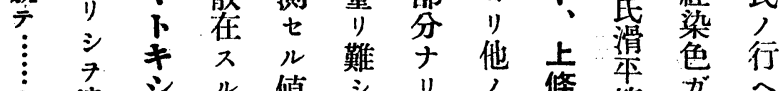
槀遺 主

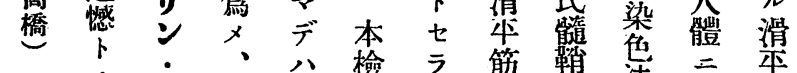

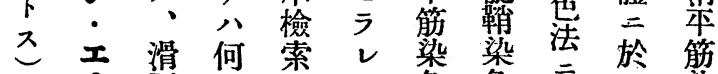

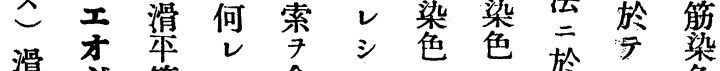

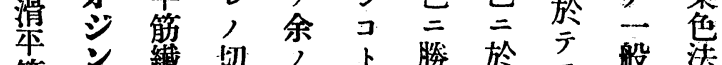

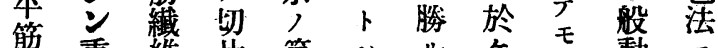

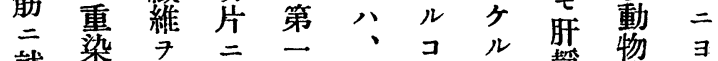
就染 思於編 余 テ 色 見於編余少同脈於少

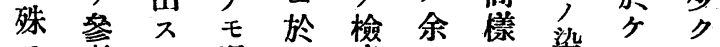

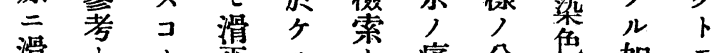
二 匴 二笳、難 7 告 較 二留動明物 七消先觉見占經 7 快二

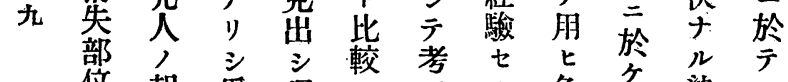
位報篇得ス较 ル色尔心 及゙告 ナ ル ル ル 所素程急渪 排ルざ、滑り 固容示箭

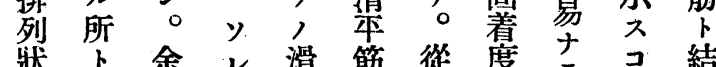

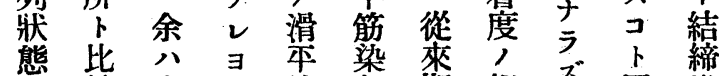
範之少色概相 ズ、困織

部云儿, 分於卜識 二テキ别 於 或 ケ碑り夕 ル所ノ容 該二㘕 易 染 於 別ナ 色 容 ラ 八易 ズ 既 滑 ナ。 二本々口 注箭 意瀻旺年 $\begin{array}{lll}\text { セ } & \text { 維 } & \text { 胿 } \\ \text { 靜 }\end{array}$ 如認胍 ク ス 啝 染 色、部云 之 分 於 黃 二 三 色續於 色柰心大 調 梢 結 體 部 締 結 關 分 織 締 係 三增 織 上於 加 ガ

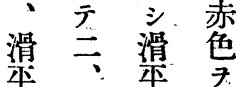
筋 三 筋 人分滑 鑑 滑 排 本 別 集 列 笳

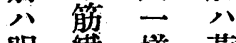
明䌯 樣 黃 確維 す 色 期走ザ亦 


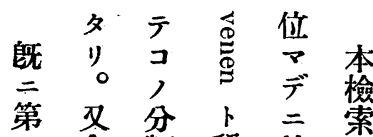

一余 類 称 就

編公寻市於

二肝り 三 $\overline{\bar{O}}$

於静言 ○云晘

テ脈へ ○ 7 靝

肝人 バ $\mu$ モ脈

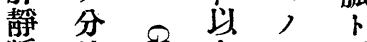

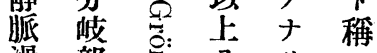

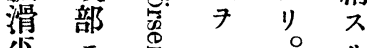

筋 就 $\cong$

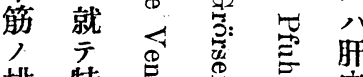

排 特 离

列 $=八$ 旰

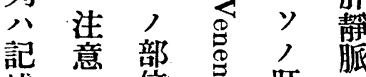

述意位 采肝

七示名䢂

所检”。名脈

所索然分主

ルルと居類圭

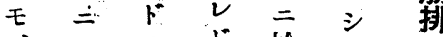

$\therefore$ 正於应列

茲劣、稍牀

簡要整余人各態

潔卜二檢於ナ

二八於菜示儿

記 全厅三八肝

七另於計䢂

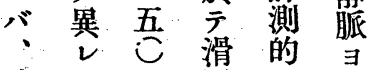

稍 $ル \mu$ 本

々 見 附 筋 九 末

大解 近 $7 \bigcirc$ 梢

ナ二言認乃八

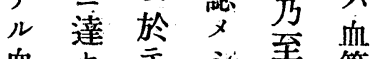

血 七 至 洷 管

管 リ モ ハ 方滑

於 後 滑

述 策 $\bigcirc \mu$ 筋

八造 筋 $\mu$ 消

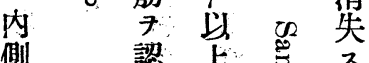

側認上

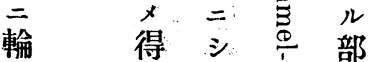

犬 Y

了用 研

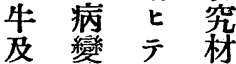

ビ分 檢 料

豚檢索 八

菜察京

比 スり 都

較 べ。帝

觀 キ 標 國

第察 血 本 嚳

第四少宫同病

項 章

肝檢

索

成

績

影 - 理

響 條 學

ナ 件 敨

キ , 辢

モ下清

) = 野

7 固 教

用定授

七站天

リ夕野

○ル 講

份 モ 師

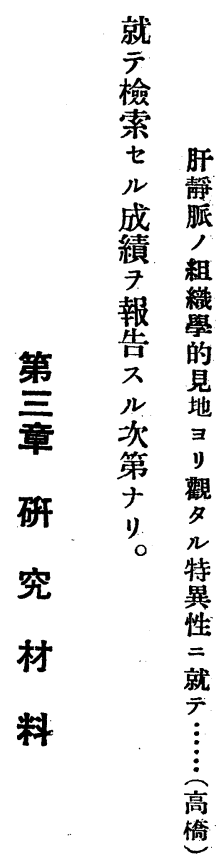

旰二御

靜 三 好

脈 意

分! =

岥出 $\exists$

部來 リ

㿁

滑 得

匴限 多

排 新

列 鮮 本

）

檢 ル 標

索 モ 本

$=1+$

當、例

中

テ $\exists$ 歐

八リ 米

特当 標

二擇

猿摆苯 


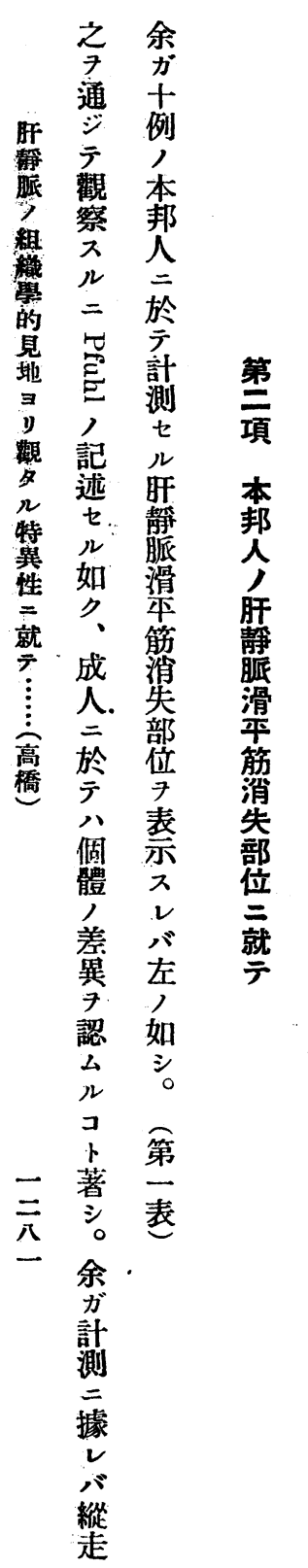

所於輪滑續血然 ス列走牀 牀

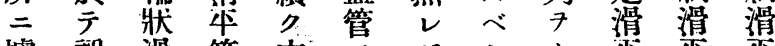

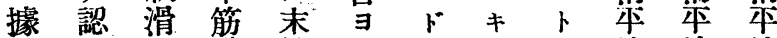
乙ム年緎 梢りモ滑儿筋筋筋 バ。筋維三更更勧モ人分僅

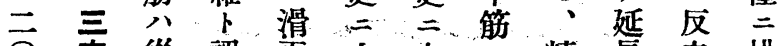
○宅從認本小十, 精長之排 ○公來 $\Delta$ 筋…分. 消細子漸列 $\mu$ 小報 ゙存ルナ失三ル次

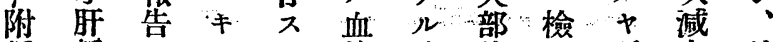
近静 七王儿管注位 三脈 $ラ$, 如三“意ハv十

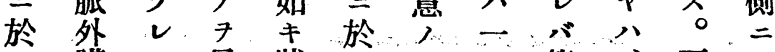
厂 膜夕見狀 テ下三第、而力

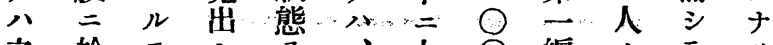

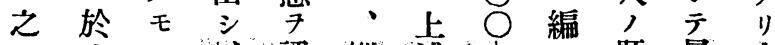

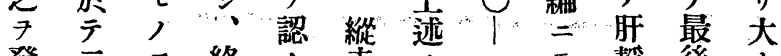

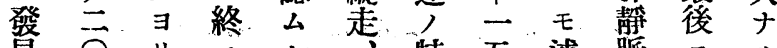
睍 $○$ ”

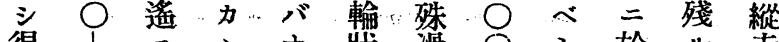
得 $1=、+$ 狀滑 0 シ 於ル走

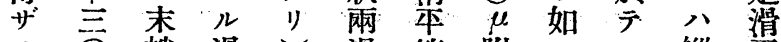

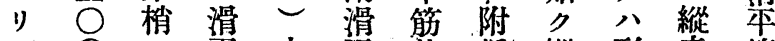

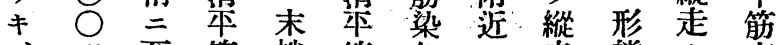
, $\mu$ 至筋 梢 筋色 三 走態 $七$ 束 之以ル瀻 7 共二シ 學ル斗 上 $、$ 維精 $=$ テ 輪的滑

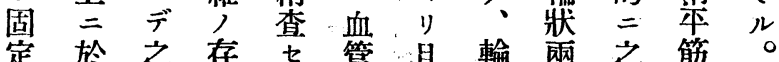

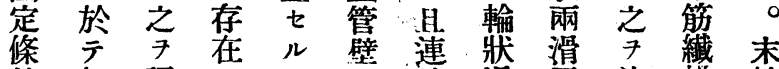
件初認七二二續滑尔決維梢 等 メ

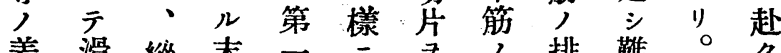

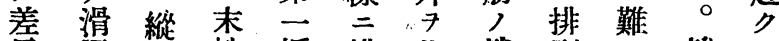
㟟 等梢編排作消列 三 然二 二筋滑 $\checkmark=$ 列

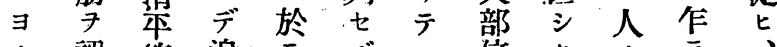

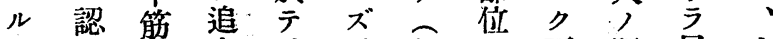
㕕咭究述、何公不肝最次

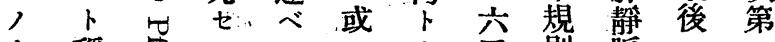
ナ稱导儿シ心ナ五則脈二二

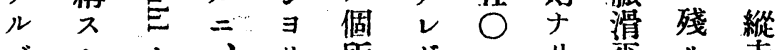

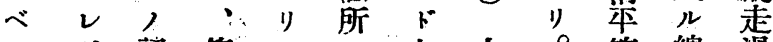

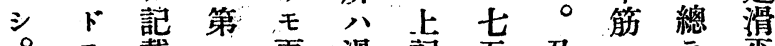
モ載 一更滑記五 又分策 七表 三本, 0 天概光筋 余 $ル$ 末 筋 直 $\mu$ 體 シ 滑 八 , $\exists$ 示梢 $\Rightarrow$ 徑附縱厅年 增 精 》 $\pi=$ 缺 7 近走叙筋 加

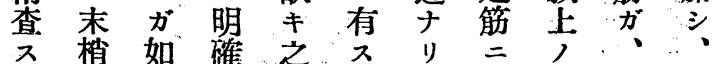

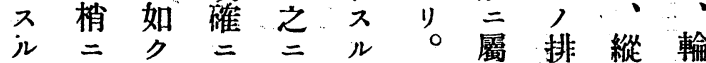


第 一表

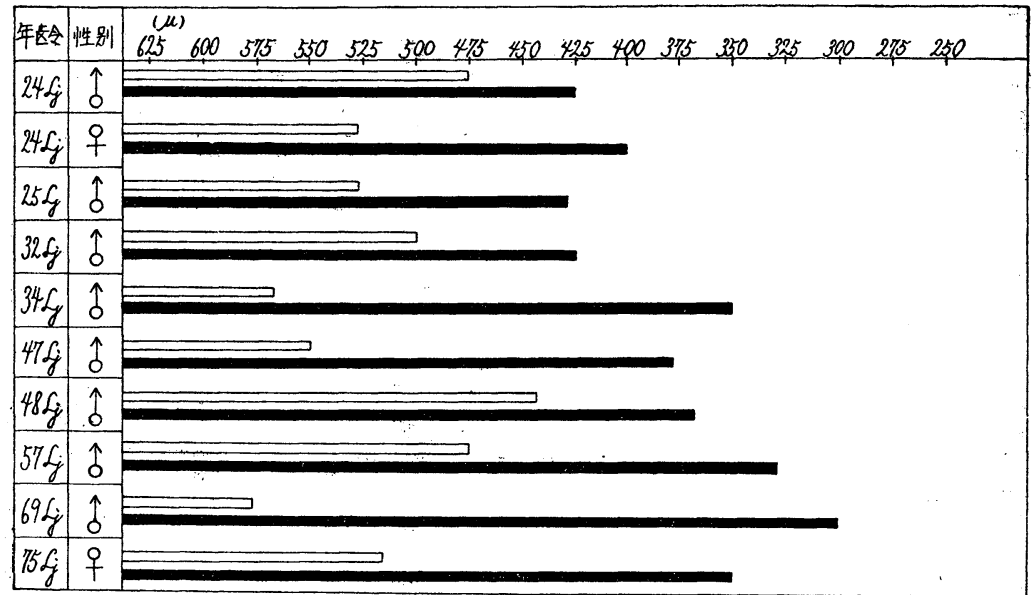

$\therefore$ : 輪狀滑本筋

$\square$ ：縱走滑平筋

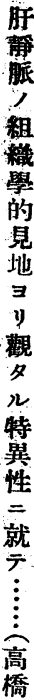

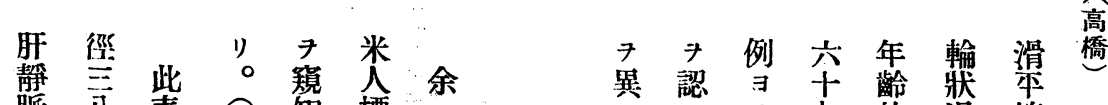

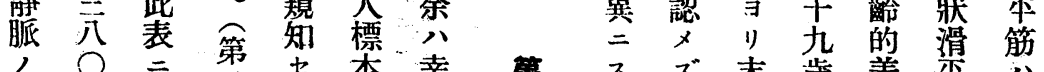

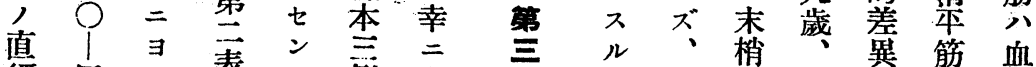

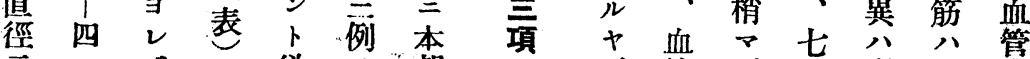
五

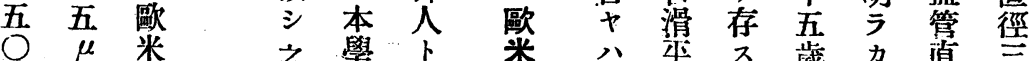

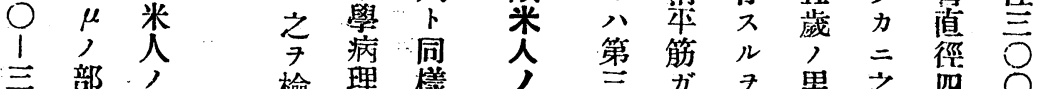

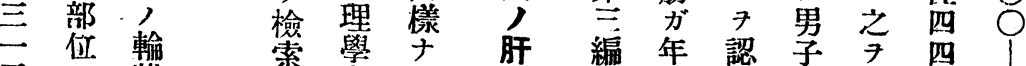
五 二 狀

$\mu$ 方, 滑

部 縱 䈘

位 走 激

ナ滑 先

リ本 部

先 筋 位

ツ 消 肝

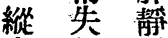

走部、脈 滑位?

平小直

等

ル 室 固

二 $\exists$ 定

次 少二

表 得

表 シ リ

如 7 保

キ 以 存

結 今

果種、

得 差…

夕暴 歐
䨋:

二齡 $么$ 二 認

○四

テ 差 輸 於 ム

詳賈狀 何 7 八 $\bar{\mu}$ 八

述二滑 $\nu$ 得 0 , 二

セヨ尔モ ザ $\mu$ 附

ンリ筋縱 リ附近

テ 二 走 シ 近二

其於滑毛二於

兵五於 テ

消八筋十莎

失此吕七消先

部關他歳先 方 
第 二 表

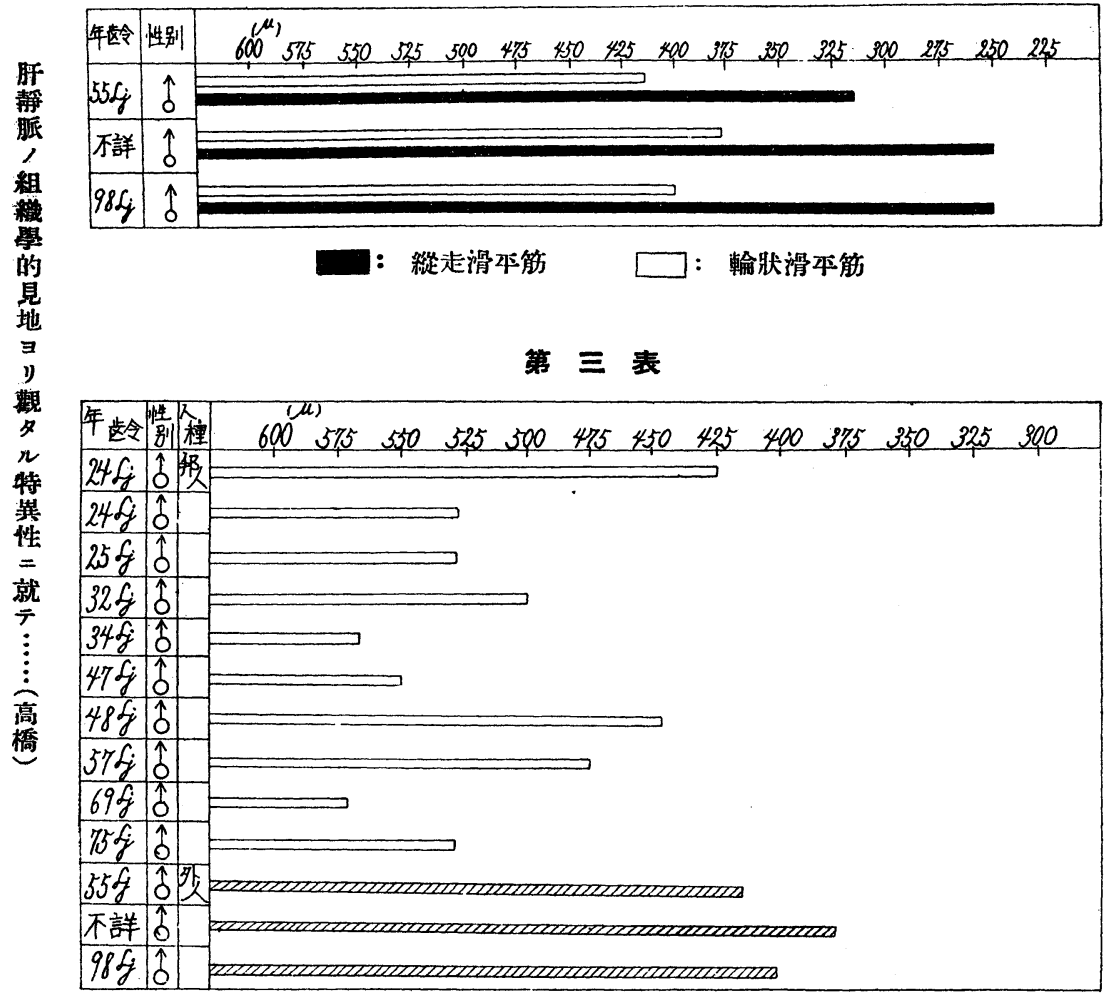

$\square ：$ 輪爿滑本筋（邦人）四原：輪状滑平筋（外人）

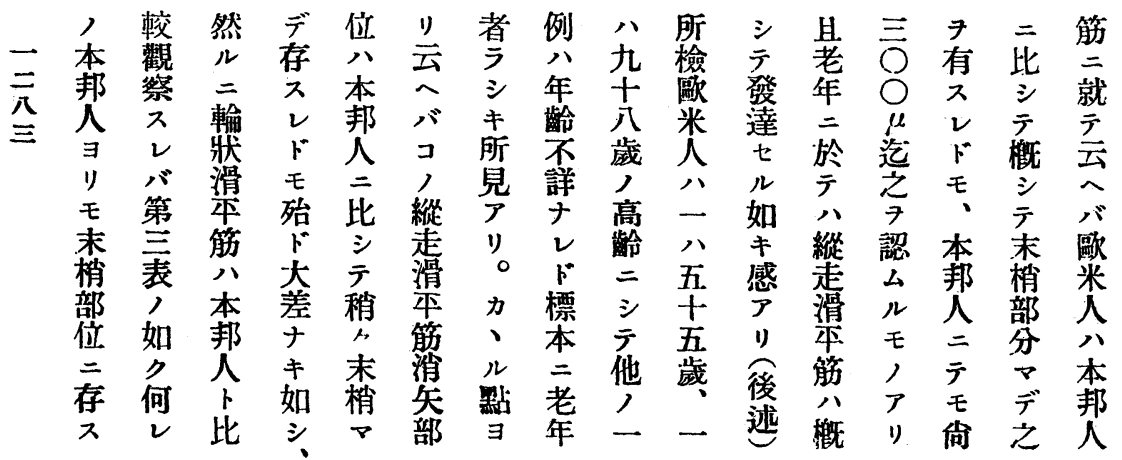




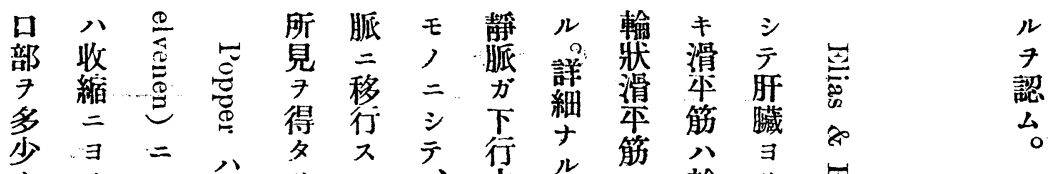

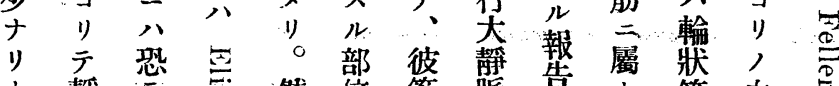

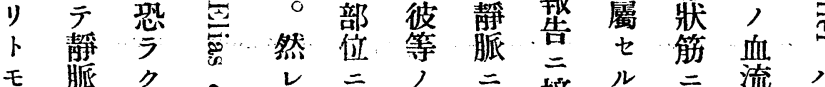

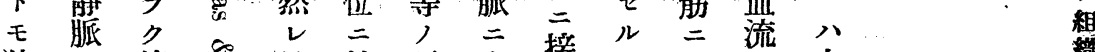

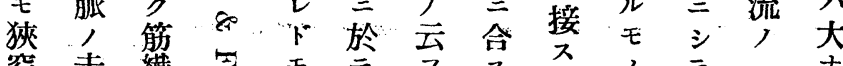

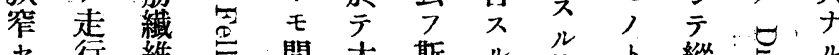

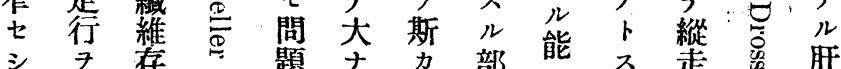

シ 7 存

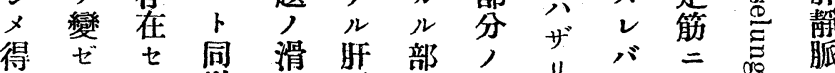

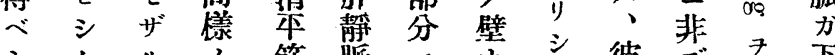

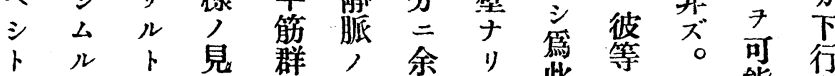

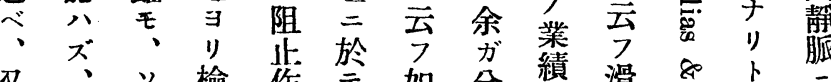

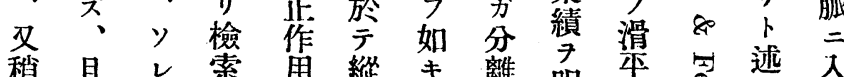

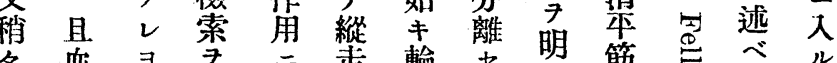

多血

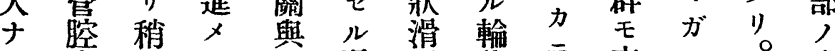

离名 $\tau$ 滑装牀批亦

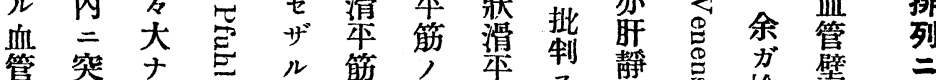

管 突

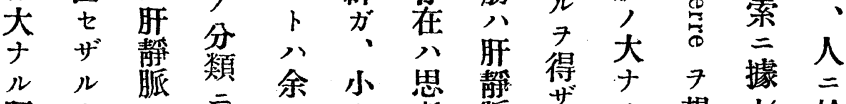

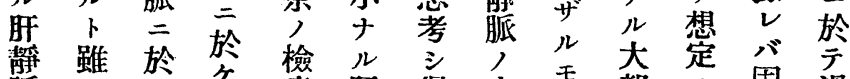

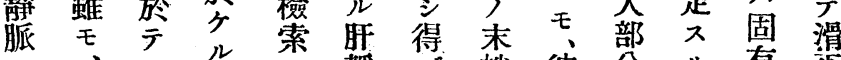

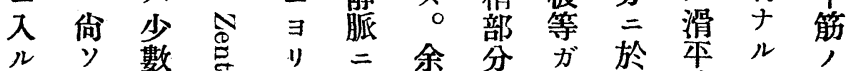

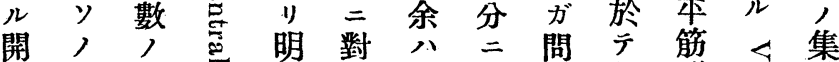

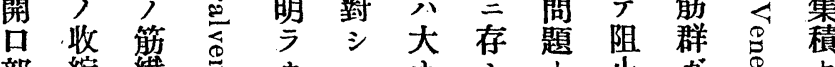

部 縮 瀻导力

二維』ナ見ル、ス作余要儿

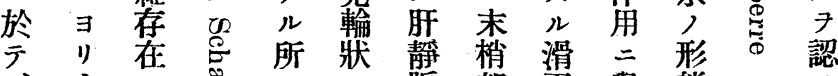

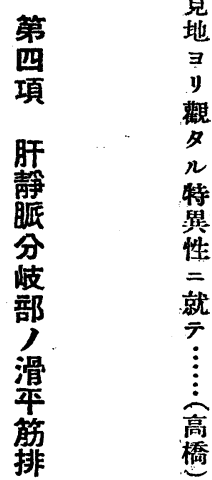

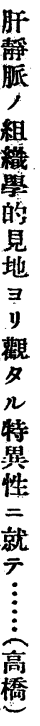

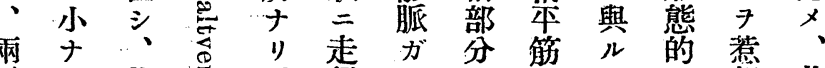

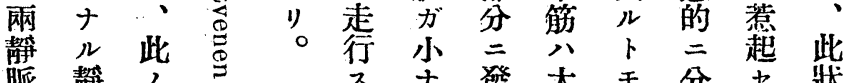

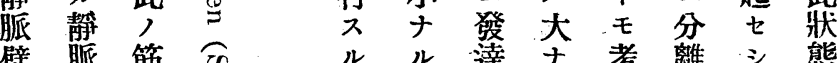

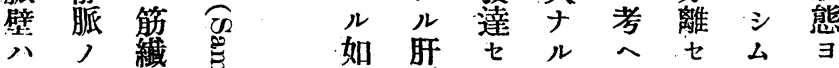
管 開維 


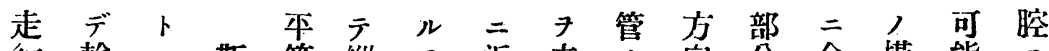
行輸 八斯筋緃王近去, 向分介横能二

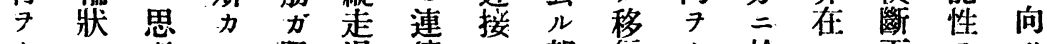
卜卜考ル阻滑續七部行卜於ス面 $7 ッ$

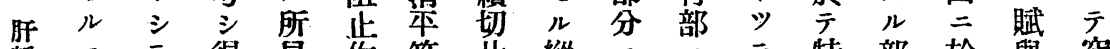

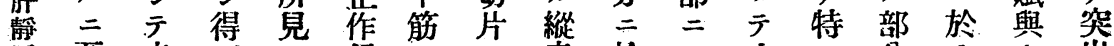

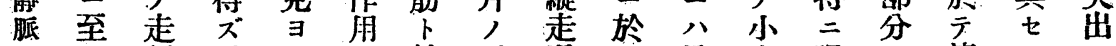
組。行

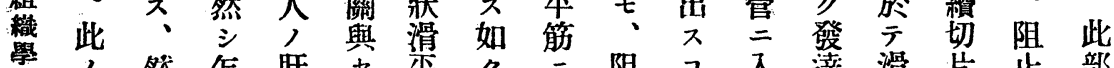

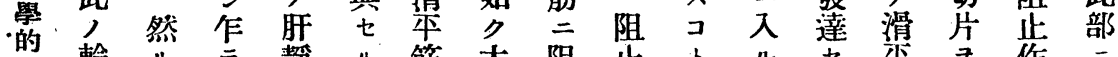
見輪 ル与 靜 ル筋大阻止卜ル七华 7 作二

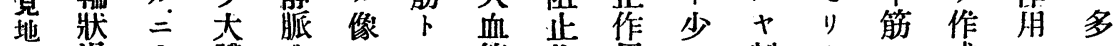

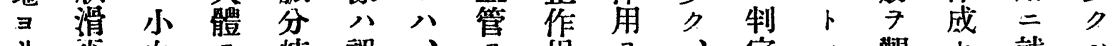

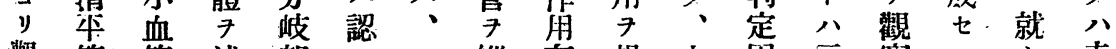
觀 筋 管 述 部 メソ縱 存 想少困云祭儿: キ 走 タ 八 ガ ブ 云 ズ、走 特 概 血 バ 性 管・血狀壬此儿阻。定 二小, 大縱管態, 縱如正然第小血 バ 就 サ 壁ナ走分当二走キ作レ゙血管、難 テク三ル 滑岐リシ滑輪用ド圖管ヨ 血キ

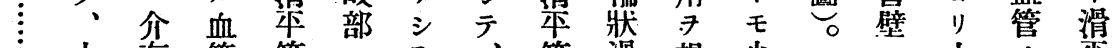

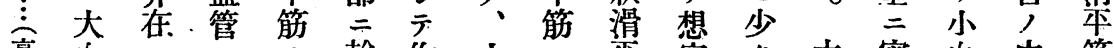

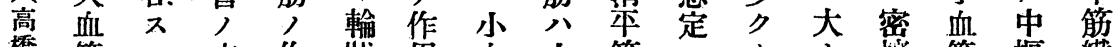
橋管 ル 主作牀用血小筋 方卜ナナ挼管梠瀻 部占用滑 二 管 血心得

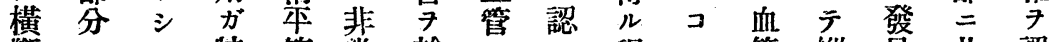

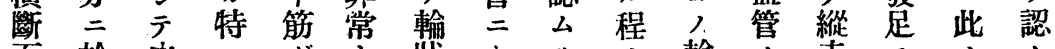

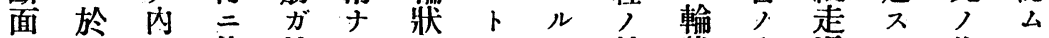
子テ 側 他 特 ル 二 7 輪牀内滑 ル作卜 見八, , 二相包テ得狀滑侧午部用述

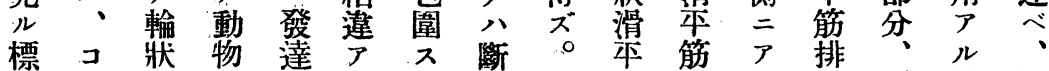
本 ノ滑二七り ル面然筋三ル列更程之

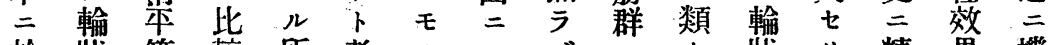
於牀筋較 所考, ヨバ 八セ牀り、精果機

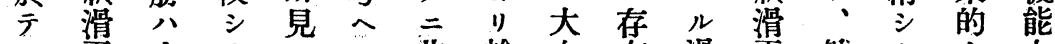

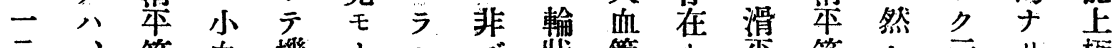
分・筋 血 機 ナ レ ズ 牀 管 七

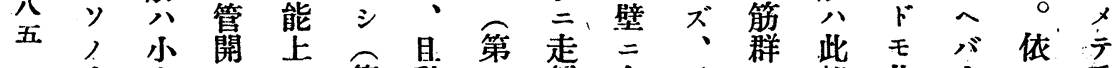
小血口了第動 一行介年 7 部此小重 血管 部 意四物 圖 管二, 義无二 開對力 7 五於 如 口シナ有六テ文キ部艻血八滑台大阻

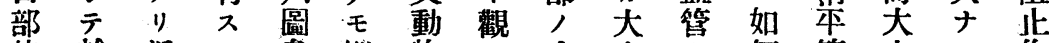
优輸近 參縱物 7 小血贞何筋血

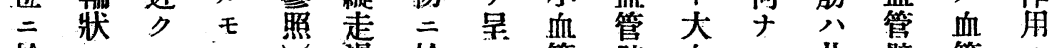

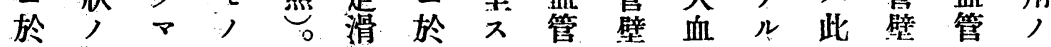




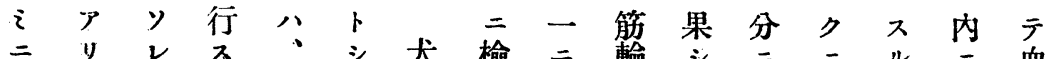

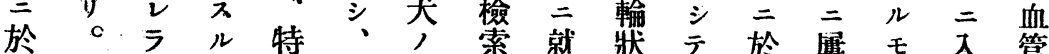
テ 然人二大

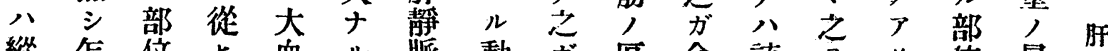

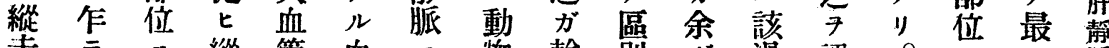
走 亏 三 縱 管 血二物 輸 別力滑認。二王脈 滑此於走, 管於, 狀分分华 既於内人

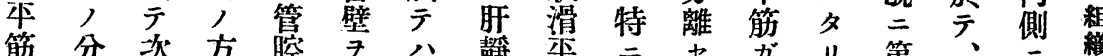

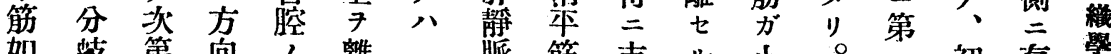

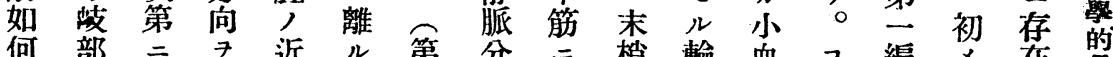
何部 $=7$ 近 第分三梢輪血コ編. . 在自

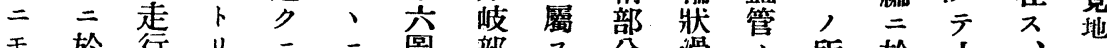

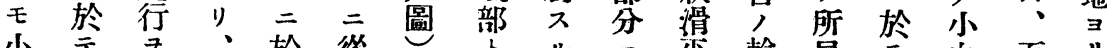
小 7 於從

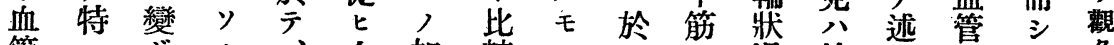

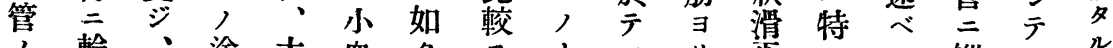
輪 將大 䃋 太

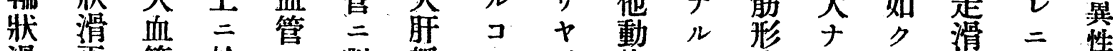

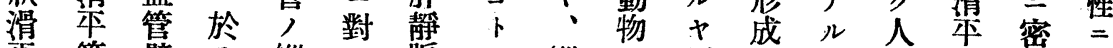
本筋 壁 テ 縱 シ 脈二縱二否二肝, 笳接就

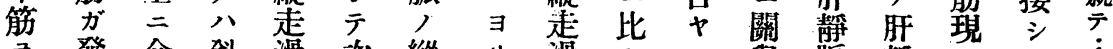

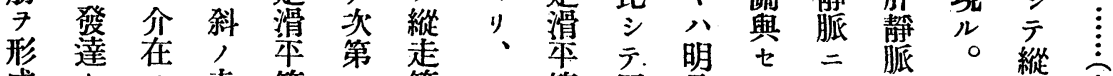

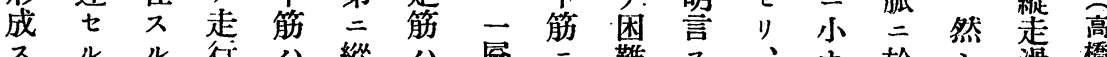

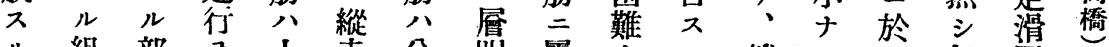
組部 如織分示血主岐確 見 像 三 於 所 管 走行 部

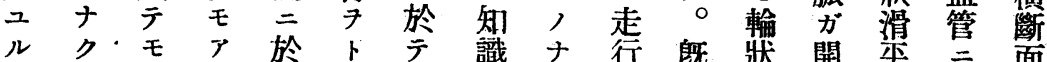
ル、既り於トテ識ナ行既狀開本二面 モ、既り。テル筋介分 連見小大割從第得ヤ規注年

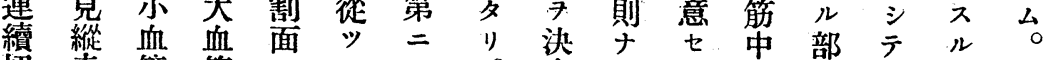
切走管 管 三 テ ソ

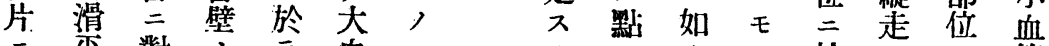
二本 對,

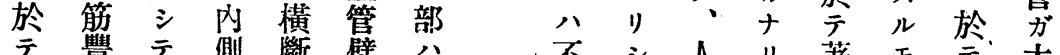

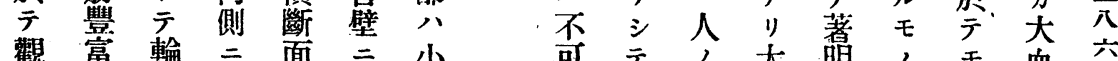
察二牀存 $尹$ 介 血 能テ、甶 ス シノス 呈在管分靜輸ルリリ量壁

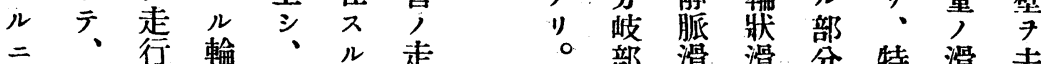
、・ 了主 滑 血 血 二 管筋

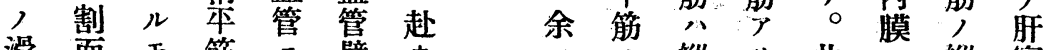

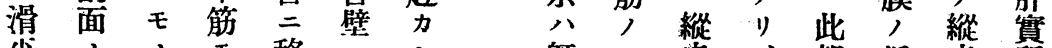

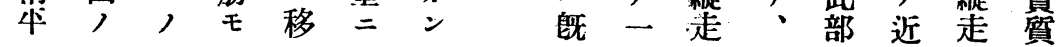




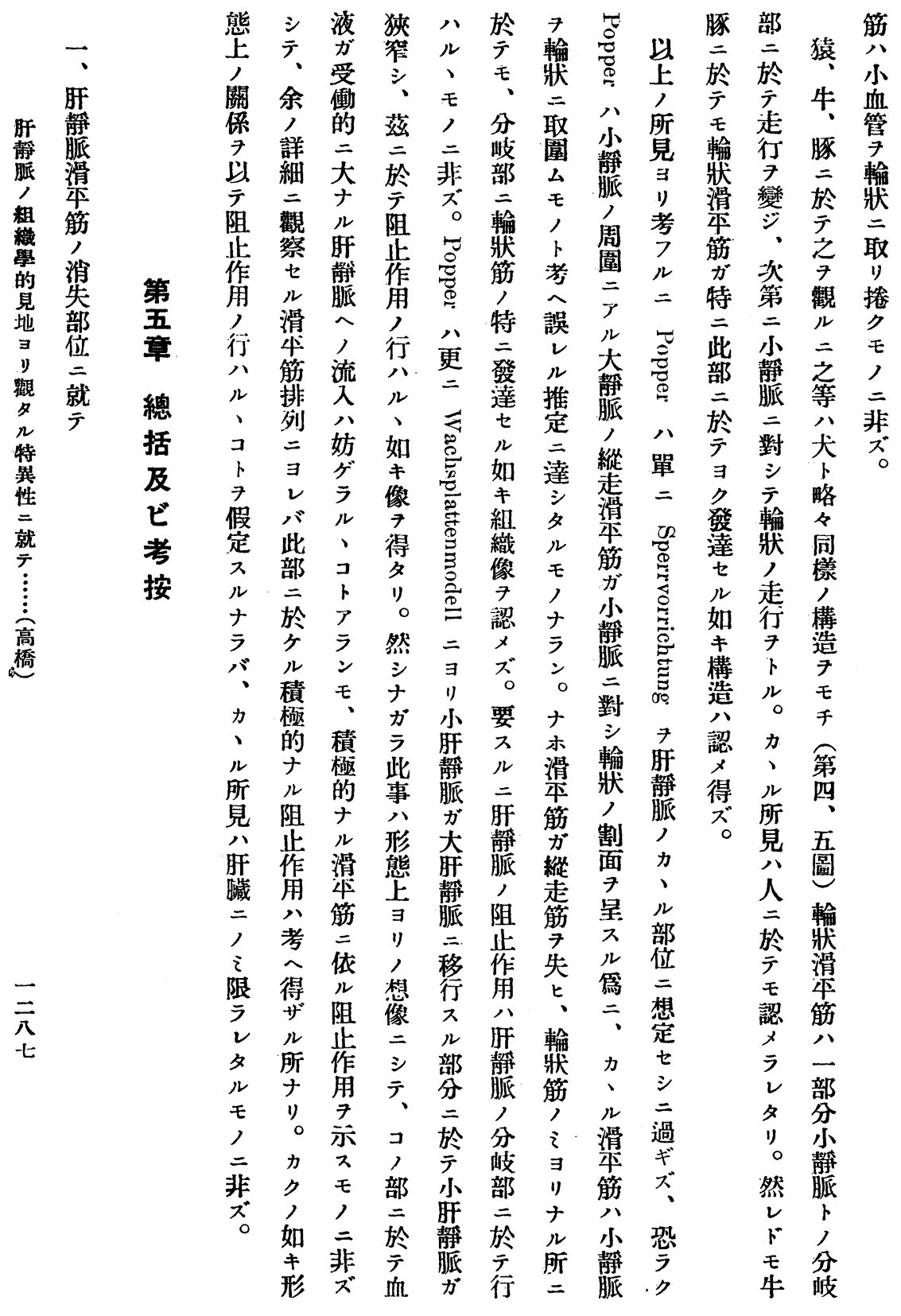




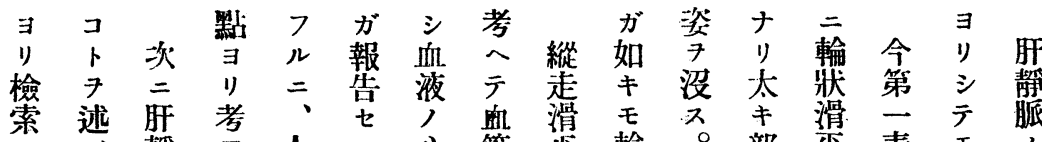

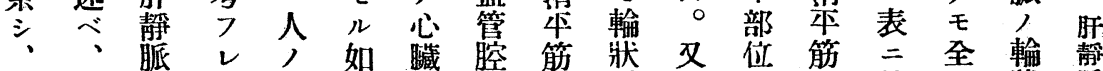

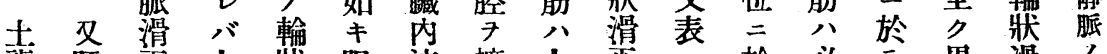
龍肝华人牀阻流擴人采三於必云異滑 二靜 筋, 滑止入灭筋見テテズ見ル本 於脈發旰尔作 7 七゙

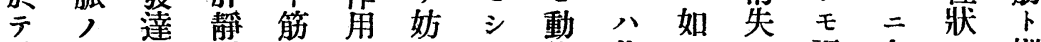
特 組程脈 心ガ グメ物此クシ本人 7 縱見 殊 織度二力人心血 7 關高、行二有走地

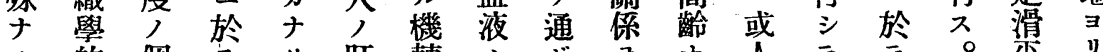

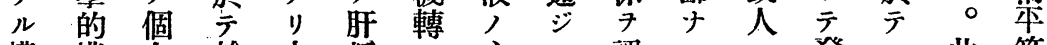
構 構人輪太静 $心$ 心認儿八發八此筋

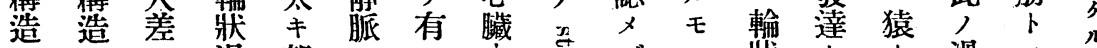

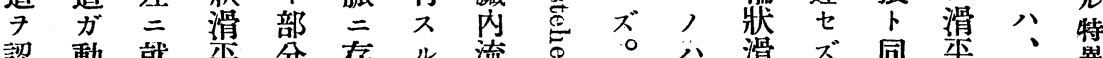

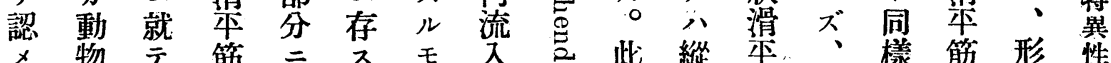
メ、物 劣 筋 三 旰種 考祭 重方

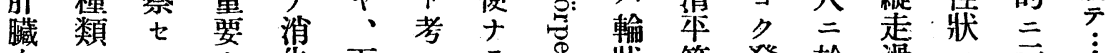

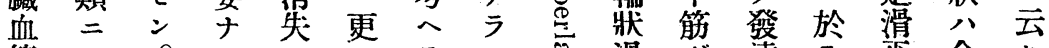

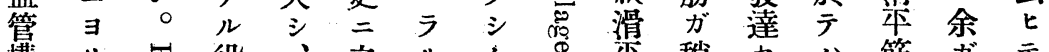

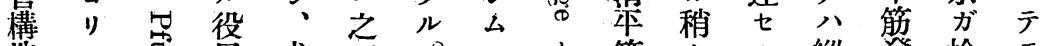

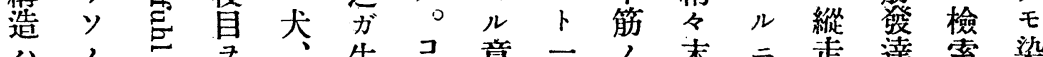
八, 7 生コ意二人化二走澾索染

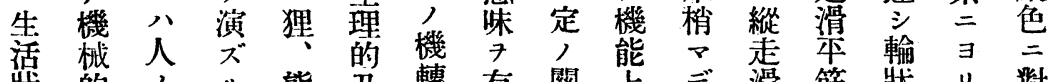

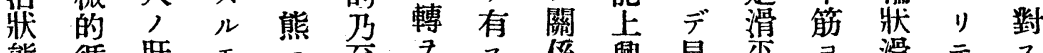

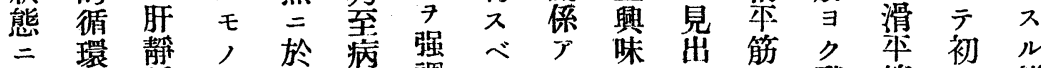

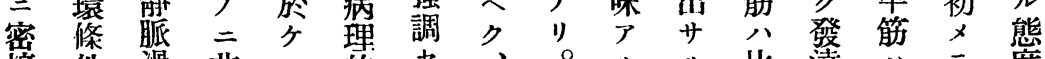

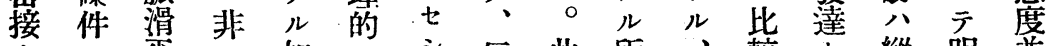
$ナ 二$ 平ル 如二シ 反此.所、較七縱明並

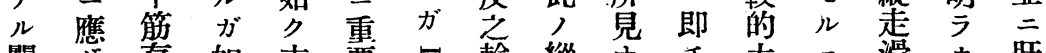

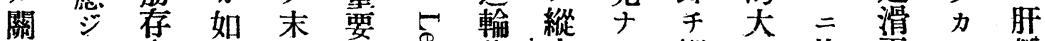

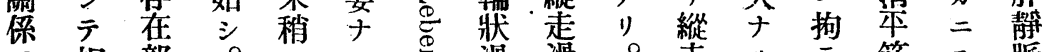
ア相部。二ル筋 ル違 位 公作导管管 コ $尹$ 見筩筋 示 個 7 人 述モ差 出持 リ 收 收 ルツ 。縮 絔 ஃ゙ノノ リ ラナ

余卜著 心前 シ 、モ 然 八 コ, トナバ管 椿 ナル 导腔 構 シ 7 导縮 前考 キ 此考导少り

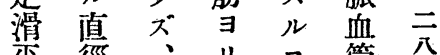

筋 徑、輸早早管公 八血 狀》 7 經 年 管 滑 渻 得 分 龄 二本失夕们 的關筋

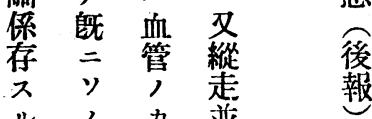




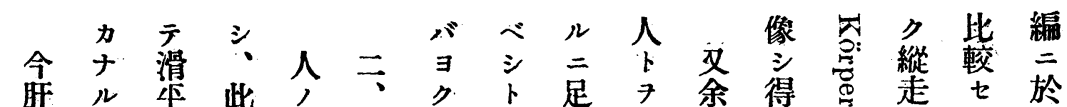

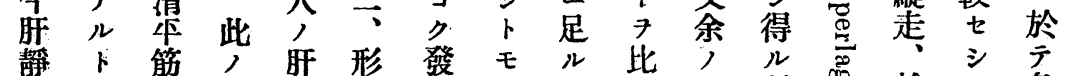

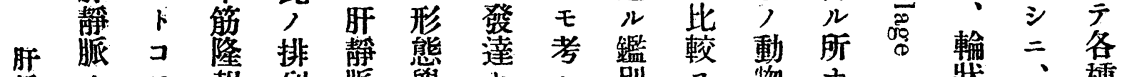

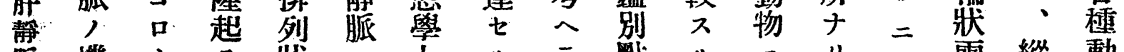

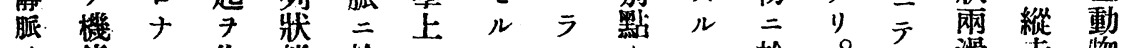

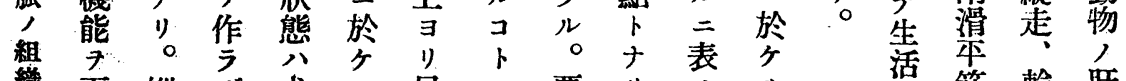

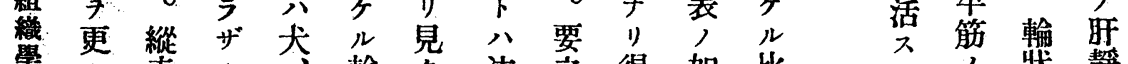

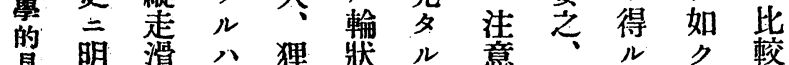

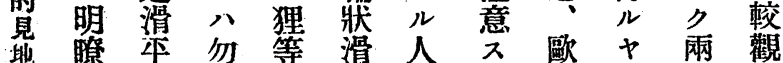
ヨ 二筋論, 策, 心来否者察 文文

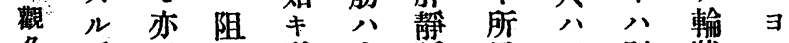
多篇、㠿滑六脈見三別牀レ 特三旰作蒤五方子例間滑バ 㓋瀧靜角筋

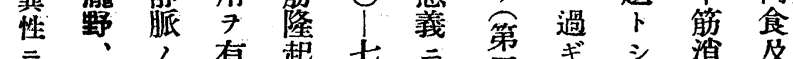

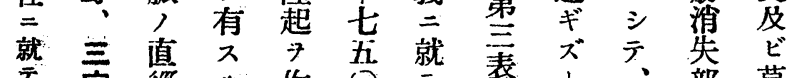
テ 宅徑儿作 $テ$ 表占、部草 $\vdots$ 三 程 $\mu$ 踓 歐 位 食

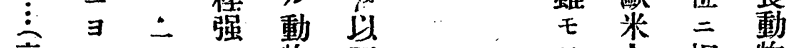

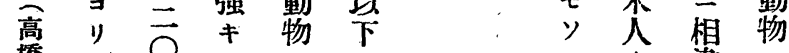

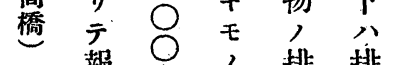
報 $\mathrm{1}$, 排排 管 $1=$ 列 列 七 一非牀 -

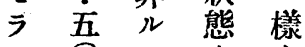
$\checkmark$ ○ 夕 0 卜 相 5 几只八促 肺 下滑多 静 = 策 脈於筋。或

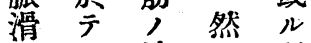
苹八消 2 所 一筋排笂占 分烈部毛公

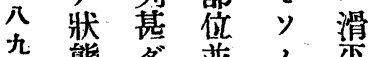
態各亚， 等

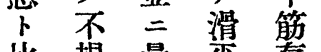
比規量等虚 䡈則䉜 厂”俰甚或 觀。寻留 察 り貧二 不琞三

人逢三 旰本基於 敖帮”。 㟲食歐輪 牀分紫䐲 滑 y人滑 年, 例 筋表僅筋 分食多 本物引發 邦 7 例達 人 異, 程 $\exists \equiv i$ 度

1) $ᄌ=$ 相

モル落

消 コ公

筷

部立枆合

，因差嘼 嘉 天買米

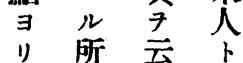
呈乺云孚 会元觙
公, 獎䢂 如排霞辳 㠰列滑滑 、複筷勧

, 释筋 笋 生”。耑粼 惟全 翼猿 境人全 堷公分人

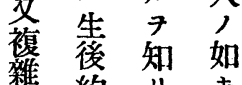

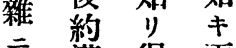
三满得電 产年多歪 人間。些 应知越

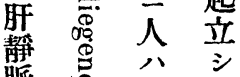
腿总最竎 力西最生 個全複活 人䂞稚

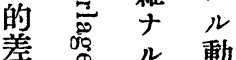
買 構物 甚示造 生年他 吕活有， 三音薢 卜的暨 八復洼 容意動 晹总堂物 想兽公如 


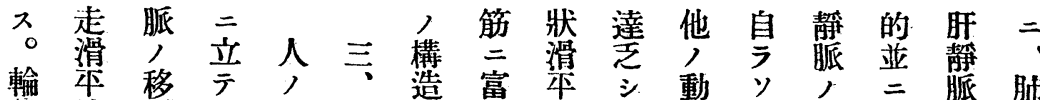
牀筋行儿旰肝卡害筋 $\neq$ 物, $i$ 病 滑八部八靜 靜 $\exists$ 公肝二意 7 埋於脈肝

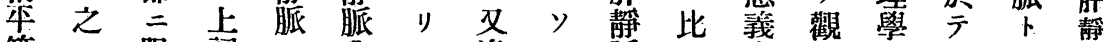
筋三阻記三分, 遥, 脈入明繁的之䏕脈 吕關歨, 阻蚑 $i=$ 排

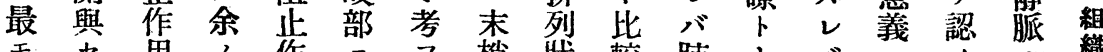

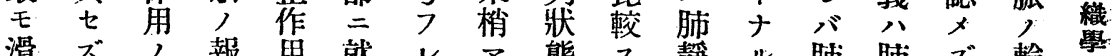

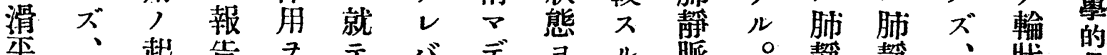

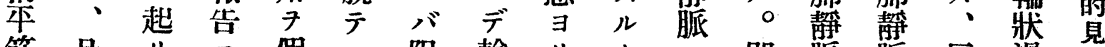

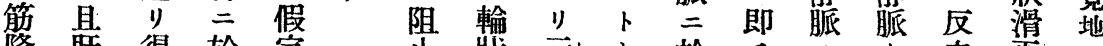

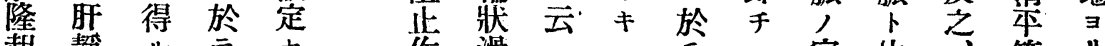
起静ル

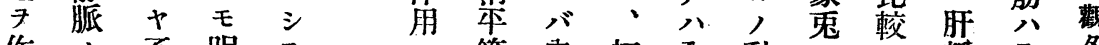
作否明毛公筋肉初全動分靜全名

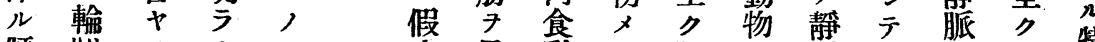

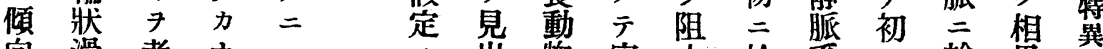

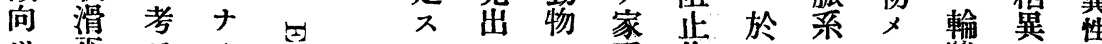

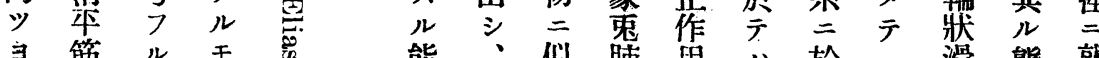
ヨ筋儿毛能、似肺角公於二滑態就

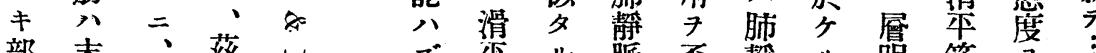

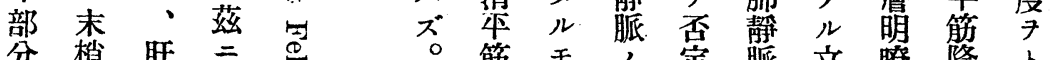

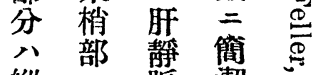

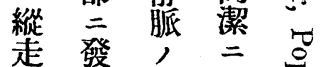
薄藮阻染密 筋

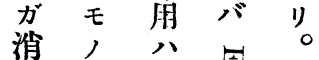

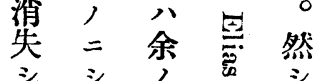
多竎检和乍 布索田

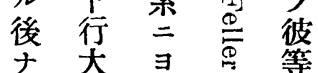
1) 静 2 , , 。脈 バ表假

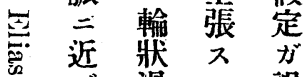
๘染 ル 誤 \% 年 兽從䈃行組 七 䢂 織 , 漸ナ脈 學 表次”在的 張減、旰檢 少縱静䇣

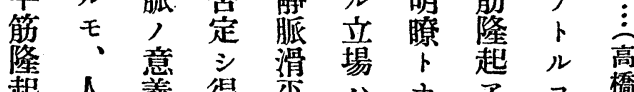

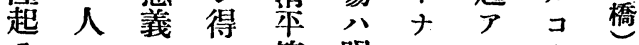
子人公能明儿ル上

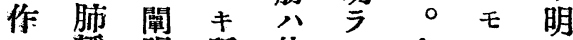

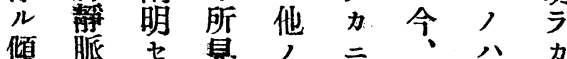

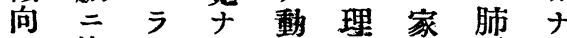

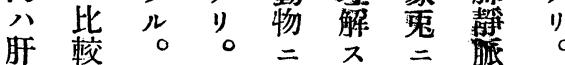
鏐公恰然比儿於三即

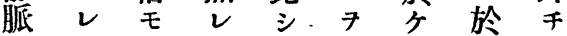

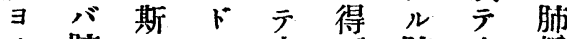

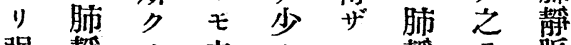
强静, 之多レ福子脈

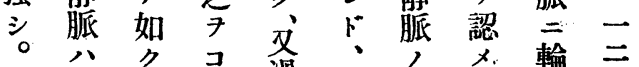

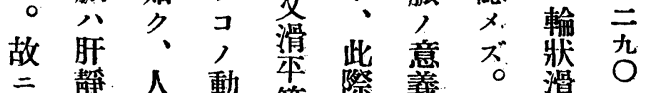

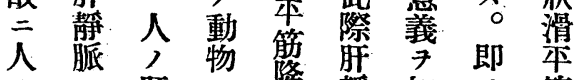

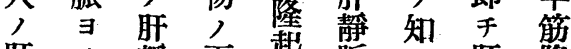

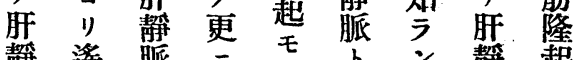

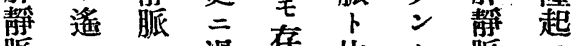

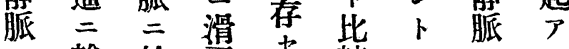

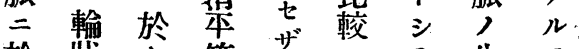

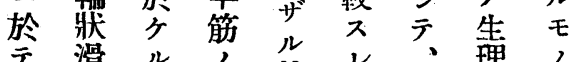

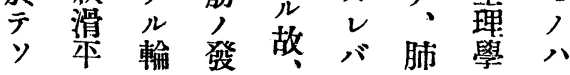


上移假コ蠟蓋縱及見次公決對云疑儿

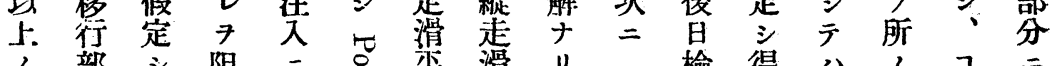

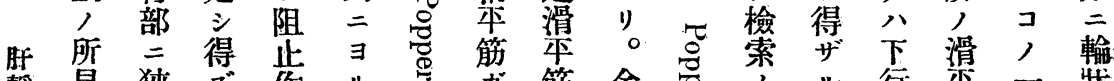

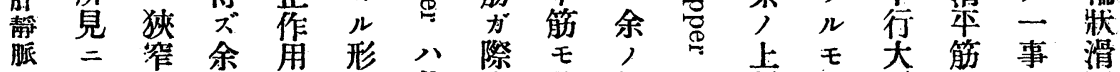

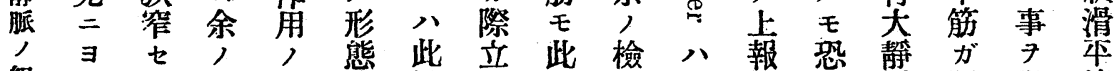

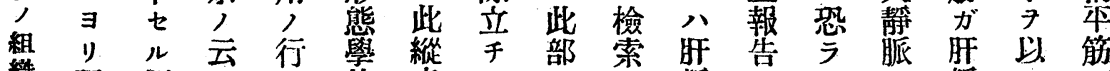

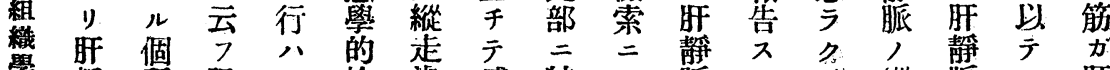

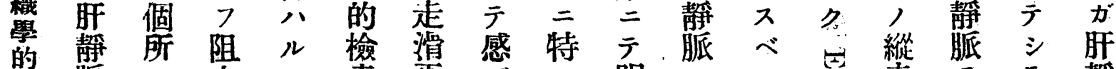

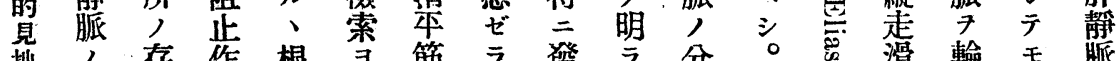
地, 存作根寻筋

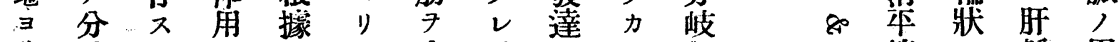
y 岐 ル 觀 部 八八七大血宛 $九 ル ニ$

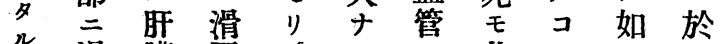

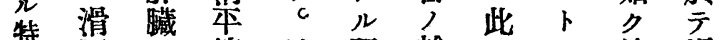
簤 策 然旰輪, モ總滑

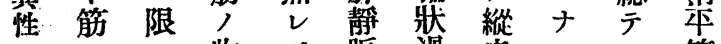

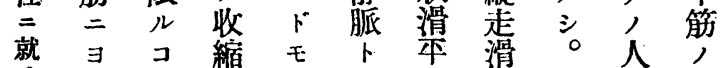
テ ル卜單小筋策單及群

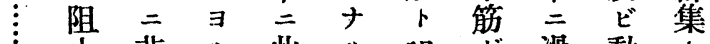

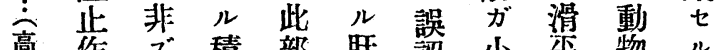
高作 ズ 皘 部䀒認小本物 ル 橋角。極分靜 せ 血筋 77

八的人脈 三管量通認

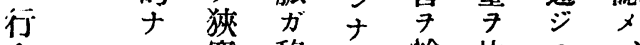

$ナ ル$ 䇤移ル輪比示

八血七行ご獎輘輸゙

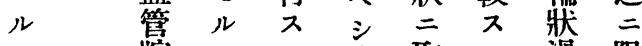

、柼コルシ取少滑阻

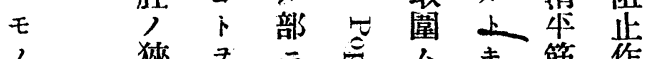

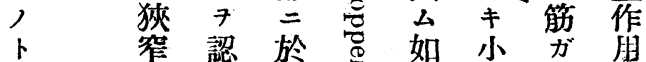

思炛公等㠰多特子

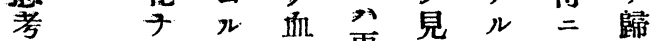

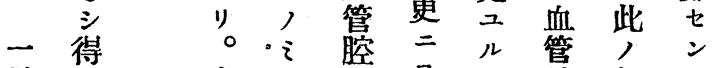

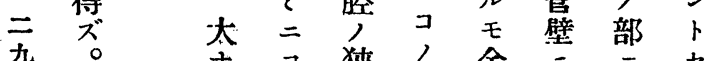

子妇塽余 $=$ t

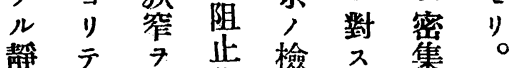

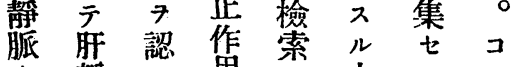

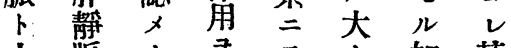

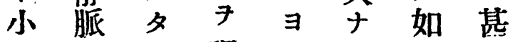

小, 》强儿江势

几阻上調, 血コ名

静歨云然管视誤

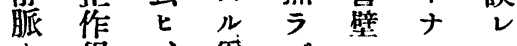

管 二 靜 周 賋取脈圍 輪卷, 7 狀り中取

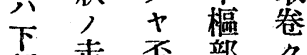

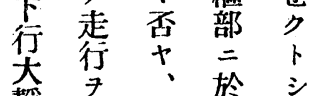

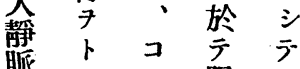

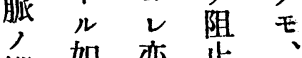

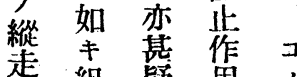
趙組簃俑, 翚織八, 滑 筋像 三行花 子文公筋 暨示兵少余 鎃得翊卟云

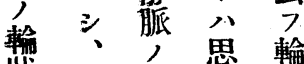

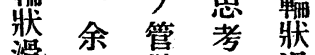
滑余䜃芌滑 乎此三得啭 筋, 全剅 品部在。 誤芬等屬 訫 $7 \pi$ 万 七檢部バル 索,

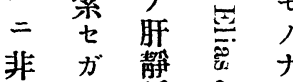
少前

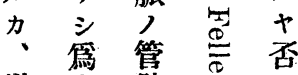

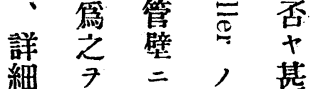




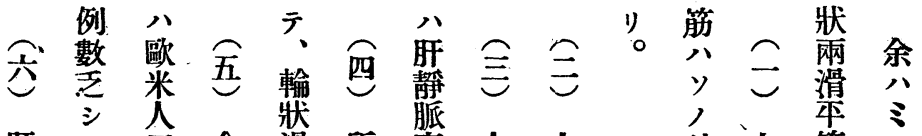
旰 $\neq \triangleq$ 余滑所直人人外人筋主

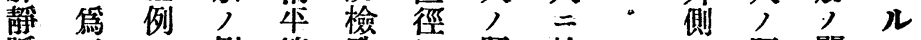

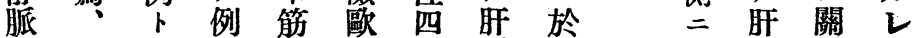

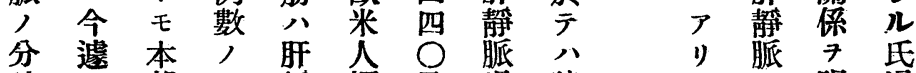
岥 遂 部之人 $\exists$ 脈染至、华二, , 動今策 二 $\exists$ 直二五筋於發物力筋

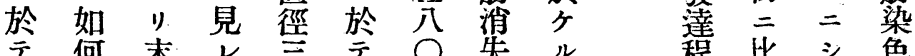

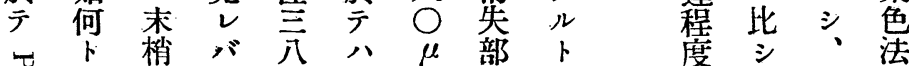
こ

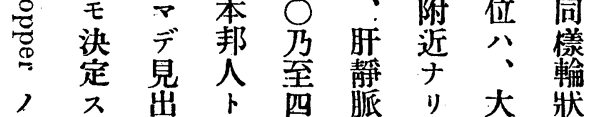
主沓出 張 7 米五果本策 得、人 $\mu$ 筋 帮箭 ル无 如。, = 湓 车 コ於筷消

阻卜文部少 止八縱。位

裝比愁走尘

置較 滑

子解 本

假剖 筋

定學 分

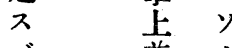

ベ亚，

滑六渻

犁部

筋 差 任

集曋 三

集卢 太

八 $\Rightarrow$

認興 認

厶 味 $x$

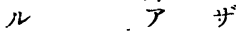

7 ル

得問 $E$

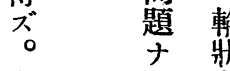

余滑

检算

縰

走

渪

筋

八 シ

輸滑本 $\exists$

獎 梁帮

滑箭人人

㘶 排上,

筋 列 歐 肝

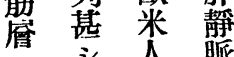
八 シ人脈 薄 夕

ク、複雃細

质

青?

織

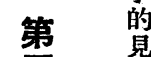

兒

章 归

結 觀

観

特

翼

性

論 就

肝

䢂縱

縱ナ走較 檢

直 滑

徑 筋

八 0 八

肝 $0 \exists$

乃

脈至 末

徑 狊

五 觉

乃 進 出

滑。次索

箅大学

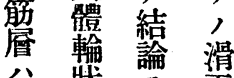

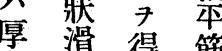

三、箭 多 䏺

且八。狀

滑秝。態

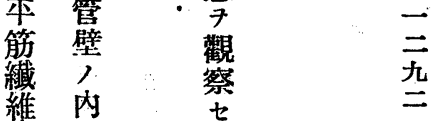

自 側 少

$=$
$\equiv$

宅 位

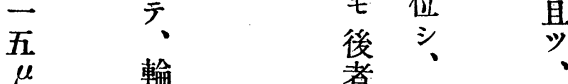

$\begin{array}{lll}\text { 方縱 } & \text { 縰 } \\ \text { 䀀 }\end{array}$

骶

筋 


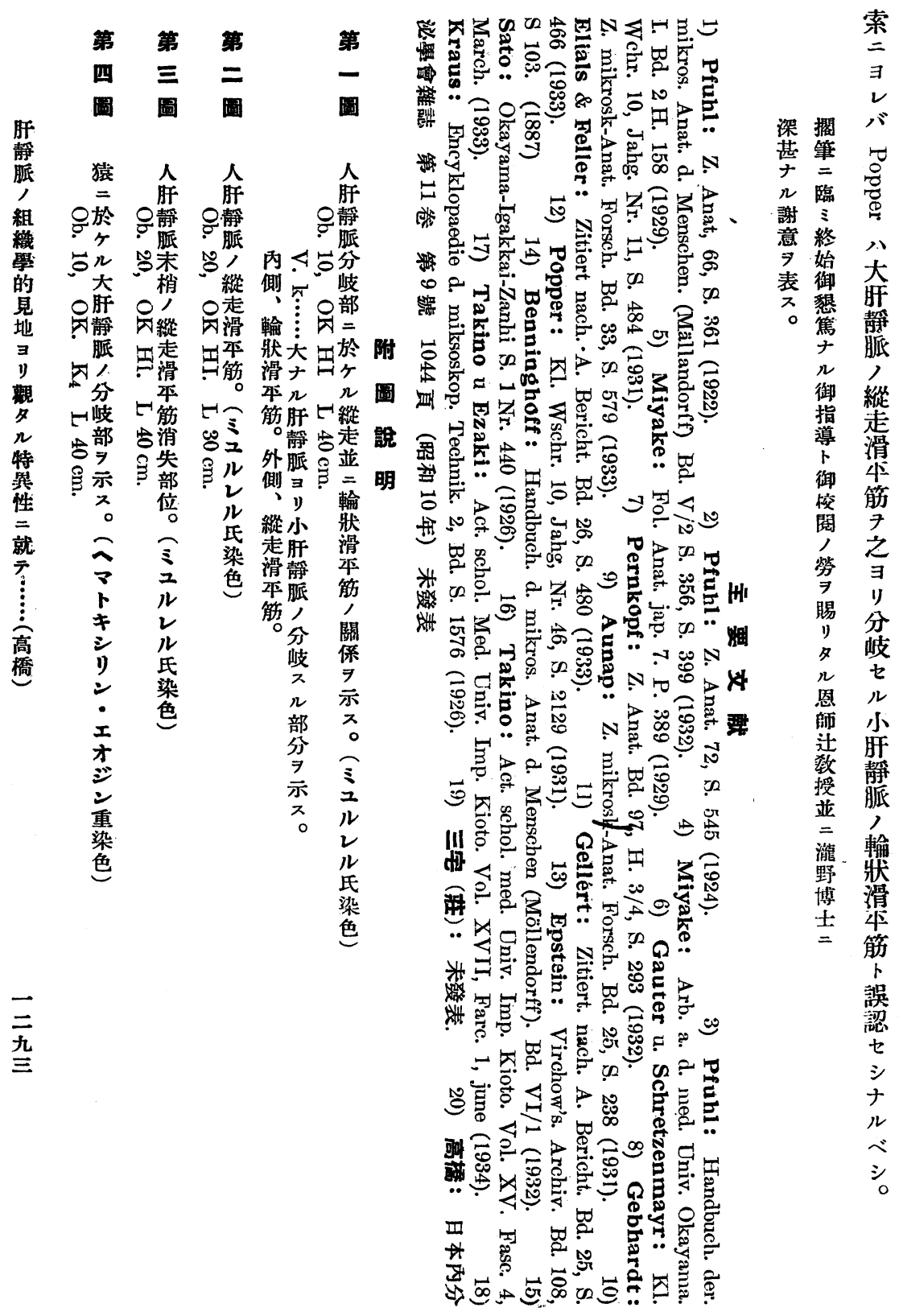




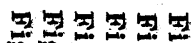
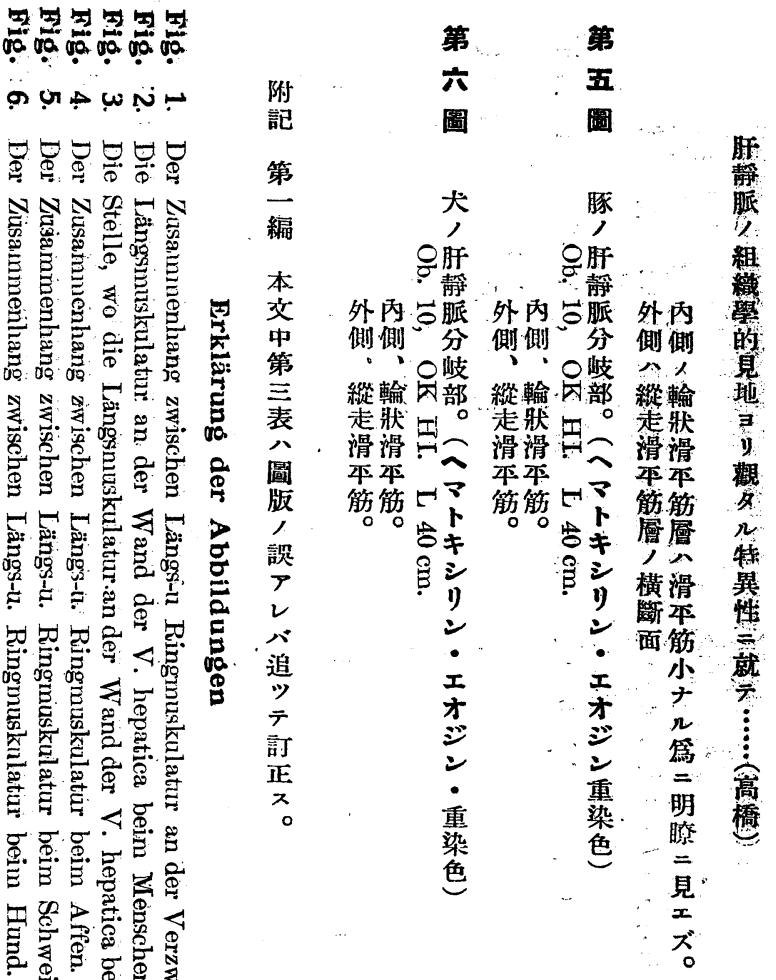

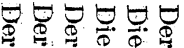

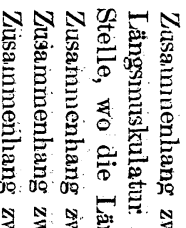

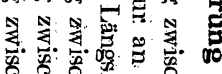

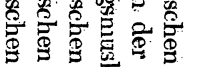

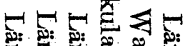

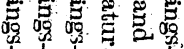

$\stackrel{1}{\prime} \stackrel{1}{=}$

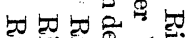

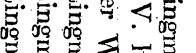

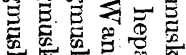

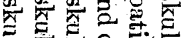

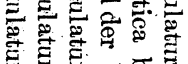

든 4 .

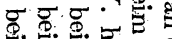

吉吉要各要

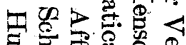

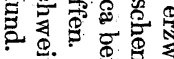

응

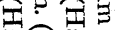

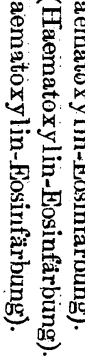

를

용요

为蛋

ट. 4 है

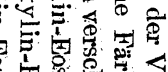

员. …

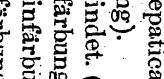

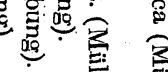

家, 客

है, 苟

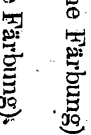


高 橋 論 文 附 圖

Fig. 1 .

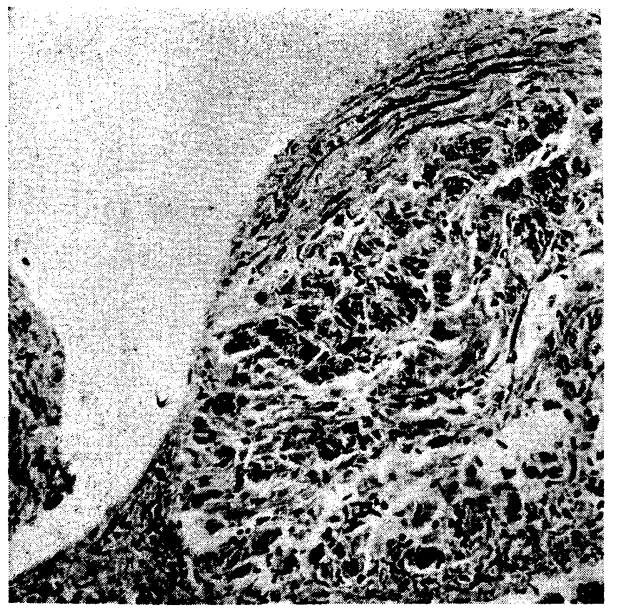

Fig. 3.

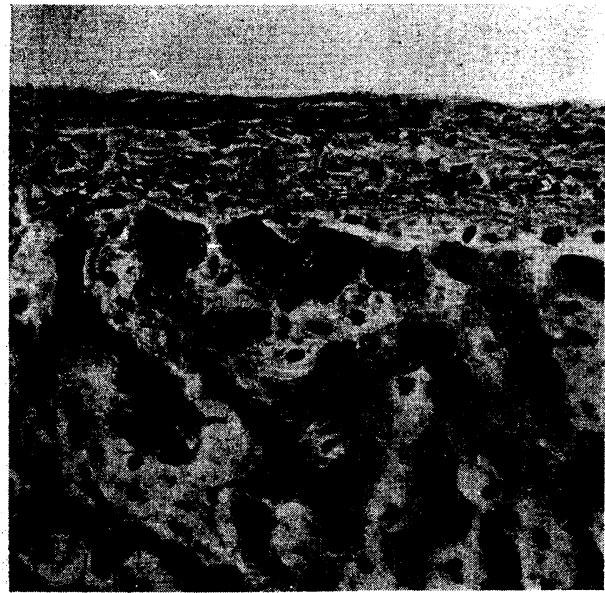

Fig. 5 .

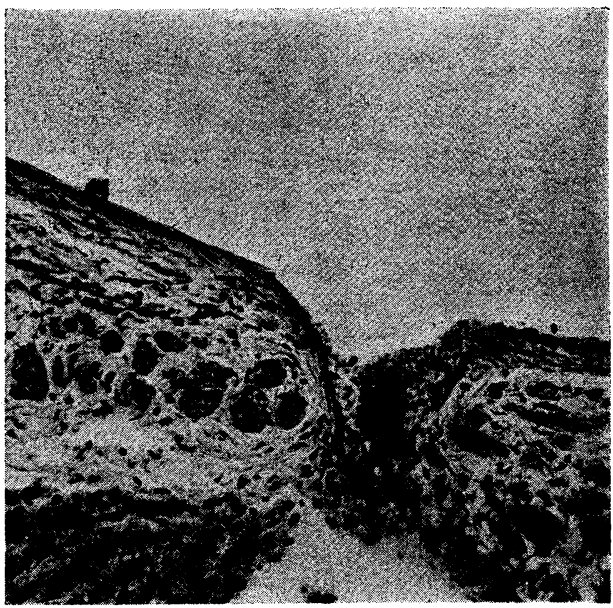

Fig. 2.

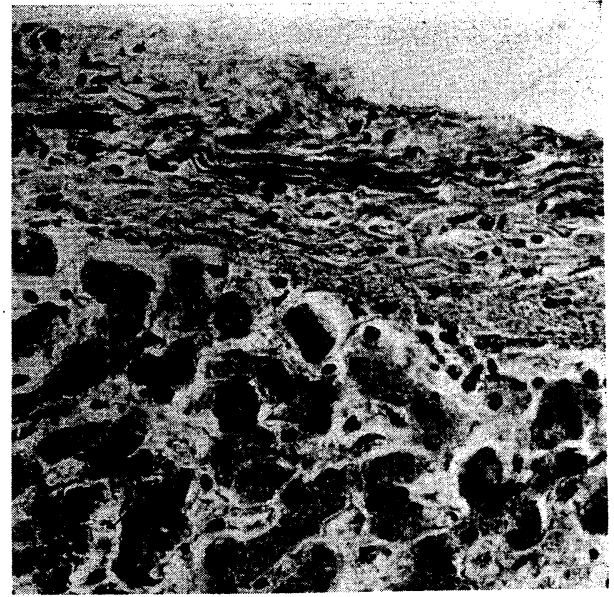

Fig. 4 .
Fig. 6 .

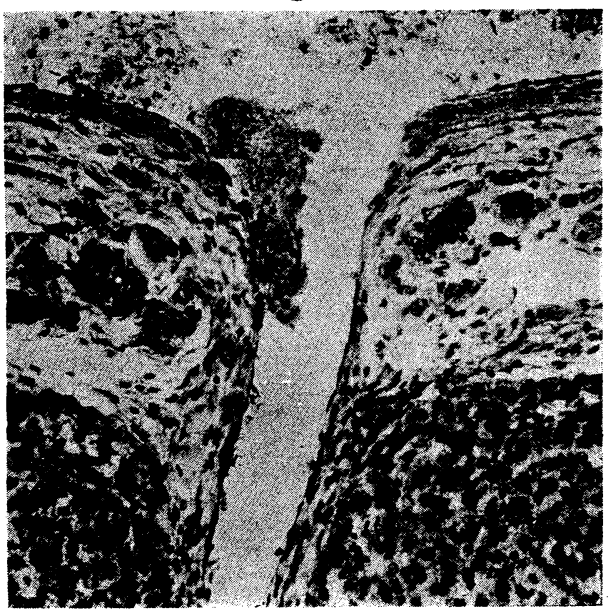


lymphgefässe zwar leicht in die Lungenlymphdrüsen zurückfliessen, meist aber nicht in die Halslymphdrüsen.

Den obigen Untersuchungen nach kann beim Kaninchen ohne Zweifel das Blut der Vena subculavia et jugularis bei Stauung durch die Lymphbahnen zur Lymphdrüse leicht zurückfliessen.

(Autoreferat)

\section{Über die histologischen Besonderheiten der Lebervenen.}

II. Mitt. Über die Stelle des Verschwindens der glatten Muskel an den Lebervenen und die Anordnung derselben an den Verzweigungsstellen der Lebervenen beim Menschen.

$$
\text { Von }
$$

Dr. M. Takahashi

(Aus der I. Med. Klinik der Kaiserl. Universität zu Kyoto in Japan. D̈irektor : Prof. Dr. K. Tsuji.)

Die glatte Muskulatur der Lebervenen beim Menschen lässt sich mittels einfacher Färbungsmethoden, wie Haematoxylin-Eosinfärbung, V a n Gi i s o n' scher Färbung usw. nicht gut färben, und so werden an den peripheren Abschnitten die schwer färbbaren glatten Muskelfasern manchmal mit Bindegewebsfasern verwechselt. Der Verfasser hat neuerlings die glatten Muskel der Lebervenen beim Menschen durch $M$ üller'sche Färbung genau gefärbt und so bessere Resultate als früher erzielt. Mittels seiner Färbung studierte der Verfasser die Stellen an den Lebervenen, wo die glatten Muskeln verschwinden, weiter wie diese Muskeln angeordnet sind, ferneer den Zusamenhang zwischen Ring-u. Längsmuskulatur. Endlich verglich er trotz seinem geringen Materiale seine Resultate hinsichtlich der Stelle des 
Verschwindens der glatten Muskulatur mit den an Europäern gefundenen.

1) Beim Menschen sind die glatten Muskeln der Lebervenen viel komplizierter als bei den in der 1. Mitteilung untersuchten Tieren. Die Ringmuskulatur verläuft im grossen und ganzen vorwiegend an der inneren Seite der Gefässwand, die Längsmuskulatur vorwiegend an der äusseren, worüber später Genaueres kommt. Die Dicke, der Ringmuskelschicht ist düun, dagegen die der Längsmuskelschicht dick, und die Muskelfassrn selbst sind bei der ersteren Schicht etwas kleiner als bei der letzteren. Die Muskeln der Ring-und der Längsmukulatur unterscheiden sich in der Grösse nicht so sehr wie bei den Tieren.

2) Beim Menschen verschwindet wie beim Affen die Ringmuskulatur zuerst und dann die Längsmuskulatur.

3) Der Verfasser fand beim Japaner die Längsmuskulatur an ca. $300-433 \mu$ weiten Lebervenenästen und die Ringmuskulatur an ca. $440-580 \mu$ weiten.

4) Beim Europäer wurde die Längsmuskulatur an ca. 250$315 \mu$ weiten Lebervenenïsten und die Ringmuskulatur an ca. 380$415 \mu$ weiten festgestellt. Beim Europäer verschwindet die Ringmuskulatur peripherer als beim Japaner, während sich hinsichtlich der Längsmuskulatur zwischen beiden Rassen kein grosser Unterschied zeigt. Ob aber dies für alle Europäer und Jap̉aner gilt, müssen noch weitere genauere Untersuchungen an einem reichen Materiale dartun.

5) An den Verzweigungsstellen der Lebervenen sind beim Menschen und bei den Tieren weder die Längs-noch die Ringmuskulatur besonders entwickelt. Wenigstens sind dort keine Muskelwülste anzutreffen. Dieses histologische Bild spricht gegen Popper, welcher unregelmässig verlaufende Muskelgruppen an den Verzweigungsstellen der Lebervenen für Sperrvorrichtung hielt.

(Autoreferat) 